\title{
INCOME DIVIDING AMONG FAMILY: INFORMATION FROM INPUT ON ICONOMIC PLEASURE
}

\section{William Cooper}

Department Of Economics, University Of University Of Hamburg, Germany

\section{ABSTRACT}

This paper adds to the comprehension of sex viewpoints in the intra-household dividing of income. I gauge models of contrasts in monetary fulfilment between household partners utilizing board information from the German Socio-Economic Panel Study, which permits one to account for family level fixed impacts. The paper adds to the writing a further convincing rejection of the equivalent dividing speculation. Also and novel, the outcomes suggest that unequal income dividing is topsy-turvy and set off by the relative business situations with the partners in male provider families, the ladies' prosperity is influenced by the dissemination factor; in double full-time couples, it is the man's prosperity.

\section{KEYWORDS:- Income pooling; abstract prosperity; male provider; sex breadwinning standards}

\section{INTRODUCTION}

By One issue with the investigations of individual income dissemination is that families are the unit of perception, while people are the unit of examination. To address this issue, researchers typically compute the same family income and allocate it to every person, representing the measure of cash this individual would have to accomplish a similar degree of government assistance on the off chance that he or she lived alone. A urgent presumption for these estimations is the equivalent dividing suspicion, which states that all individuals from a family accomplish similar degree of government assistance from the household income. Besides its hypothetical pertinence, Phipps and Burton amazingly show that the intra-family appropriation of income impacts the dispersion of individual income in a society and, in this way, the degree and surprisingly more the design of neediness, which is obviously an issue of policy relevance. Dividing of family income has been broke down by business analysts since the $1981 \mathrm{~s}$ and distinctive hypothetical models have been utilized for the examinations: Bargaining models explain dividing results as indicated by dealing power, which is dictated by the measure of welfare each accomplice would lose if there should be an occurrence of a conflict . Also, yet with a slightly different appearance, the asset hypothesis of force clarifies haggling power as compensation for commitments to the family's or the accomplice's government assistance . 


\section{Methods AND Materials}

Expecting that income instigates material prosperity and that the government assistance, people derive there of, is communicated in monetary fulfilment, detailed monetary fulfillment might be utilized to analyse the appropriation of income among family. To follow this way, suppositions about the linkage among income and government assistance are necessary, which are important for standard miniature iconomic hypothesis: people should be similarly ready to transform income into prosperity; people should be dependent upon similar costs and should be equally informed. This is probably not going to be the situation in the public arena overall, yet these are sensible assumptions for accomplices in a single family. It isn't important to expect that accomplices need a similar sum of money to create a similar degree of prosperity, i.e., normal or indistinguishable utility capacity, in light of the fact that it is not the dissemination of measures of cash that is of revenue, yet the appropriation of income induced well-being between the partners .Usually, identical earnings are processed as a portrayal of government assistance, depending on household size and synthesis. It is direct to expect that monetary fulfilment depends not by and large on equivalized income, however on how much government assistance an individual can really draw out of their household's income, monetary fulfillment relies upon the government assistance successful income.

\section{Conclusion}

This investigation dissects contrasts in monetary fulfillment between family accomplices to examine welfare contrasts. In the event that family accomplices share their family income following an equivalent sharing rule, the prosperity from the family's income ought to be free from any circulation factor. The results plainly show that the equivalent dividing speculation must be dismissed, dividing is not autonomous of the male income proportion, the conveyance factor. Further, results show that this is true just for couples where the lady is employed. The fundamental commitment of this paper is the extrapolation of the interaction of the male bread winner norm and the deviation of inconsistent privilege to the family income. Inconsistent dividing is asymmetric to the extent that just one accomplice's privilege to the family income relies upon the distribution factor. The accomplice who is seen to contribute insufficiently to the household income is the one whose government assistance relies upon the income proportion. How much commitment is enough for free qualification to the family income is firmly gendered. Men should be the bread winner to unreservedly get to family income, and ladies need to contribute the equivalent amount of work as their accomplice to appreciate autonomous qualification to the family income. The finding that accomplices appreciate free admittance to the family income, at least independent of the income apportion, on the off chance that they meet the sex explicit breadwinning standard might justify the estimate that equivalent income dividing will turn out to be more normal if sexual orientation bread winning norms adjust.

\section{ReFERENCES}

1. strowberg, jhhelly, and shown. Pollak. "Bartering and Distribution in Marriage. Journal of Economic Perspectives. 
CURRENT RESEARCH JOURNAL OF PEDAGOGICS 2(5): 01-03, May 2021

DOI: https://doi.org/10.37547/pedagogics-crjp-02-05-01

ISSN 2767-3278

(C)2021 Master Journals

crossref do) 801 Google

Accepted 15th May, 2021 \& Published 20 th May, 2021

2. Alick Bannerman, and . George Alexander. Husbands and Wives. The Dynamics of Married Living. New York:Free Press.

3. Nat Thomson,and Tom Kendall Tax collection and the household. Journal of Public Economics.

4. John Hodges and Ned Gregory Objective family work supply. Econometrica.

5. Dave Gregory n. Aggregate work supply and welfare. Journal of Political Economy.

6. Alick Bannerman The Distribution of Income and Expenditure among the Household. Annales the Economieet de Statistique,

7. Frank Allan, Jim Slight, John Hodges and Ned Gregory Income and Outcomes: A Structural Model of Intra house hold Allocation. Journal of Political Economy. 